\author{
But a committee vote - which \\ still has to be approved by \\ 옹 the whole conference - did \\ 岃 approve a need for export \\ permits to protect oceanic \\ $\checkmark$ whitetip (Carcharhinus \\ longimanus), porbeagle \\ (Lamna nasus) and other \\ species of shark.
}

\section{Quake appeal}

Six scientists and a government official who were found guilty of manslaughter after the 2009 earthquake in the city of L'Aquila, Italy, have all filed appeals against the verdict in time for a 6 March deadline. Last October, a prosecutor sentenced each of the seven men to six years in prison, arguing that their reassurances led to the wrong messages being given to the public, adding to the death count in the earthquake (see Nature 490, 446; 2012). Their sentences are suspended pending the outcome of the appeal. See go.nature.com/ vny9un for more.

\section{Antibiotic warning}

The British government's leading medical adviser said on 11 March that bacteria that are resistant to antibiotics should be placed alongside pandemic influenza and terrorism on the list of national security threats. medical officer (pictured), called for more international Sally Davies, England's chief

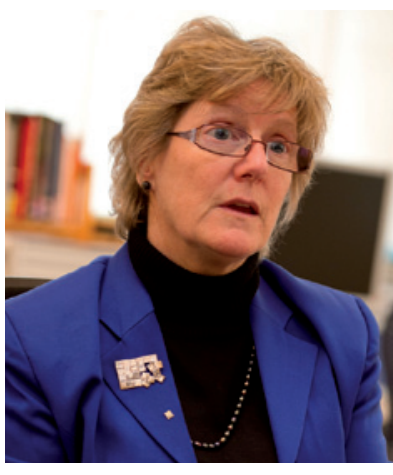

research into new antibiotics and better surveillance of resistant microbes, in a report that charts the increase in drug-resistant bacterial infections. See go.nature. com $/ 2 \mathrm{u} 9 \mathrm{ofh}$ for more.

\section{Cancer strategy}

To fight the growing global burden of cancer, countries must boost research and develop national control plans for the condition, says a panel of experts from 15 countries. The report, published on 6 March Sci. Transl. Med. 5, $175 \mathrm{~cm} 2$; 2013), calls for a series of efforts including increased funding for cancer-prevention research, harmonization of international clinicaltrial practices and global standards for biomedical research. The report's recommendations were the culmination of two meetings, the last in November 2012, (H. Varmus and H. S. Kumar of representatives from organizations that fund or conduct research. See go.nature.com/pxhoto for more.

\section{BUSINESS \\ Drug spending}

For the first time in more than two decades, the US public's spending on 'traditional' prescription drugs - therapies for common conditions such as raised cholesterol or high blood pressure - declined in 2012, according to a 5 March report by Express Scripts, a company in St Louis, Missouri, that manages pharmacy services. But the 1.5\% drop in traditional prescription medications was more than offset by an $18.4 \%$ surge in spending for drugs that are used to treat complex diseases such as cancer and rheumatoid arthritis, and that often require special handling. Overall, US drug spending increased by $2.7 \%$.

\section{PEOPLE}

\section{Pasteur head} 8 March appointed the next director-general of the Pasteur Institute in Paris. Bréchot, currently vice-president for medical and scientific affairs at the Mérieux Institute in Lyons, was a former head of INSERM, the French national
Christian Bréchot was on

\section{TREND WATCH}

New connections of solar photovoltaic systems to the electricity grid fell in Europe for the first time last year, to 16.6 gigawatts (GW; see chart). Government withdrawals of solar subsidies helped to drive notable drops in Spain and Italy. But the non-European market expanded much faster, to more than $13 \mathrm{GW}$, meaning that the global total for 2012 reached $30 \mathrm{GW}$ - not quite as much as in 2011, according to preliminary figures from the European Photovoltaic Industry Association in Brussels.

\section{SOLAR EXPANSION SLOWS}

Cumulative global solar photovoltaic (PV) capacity reached more than 100 gigawatts (GW) last year - but annual installations fell.

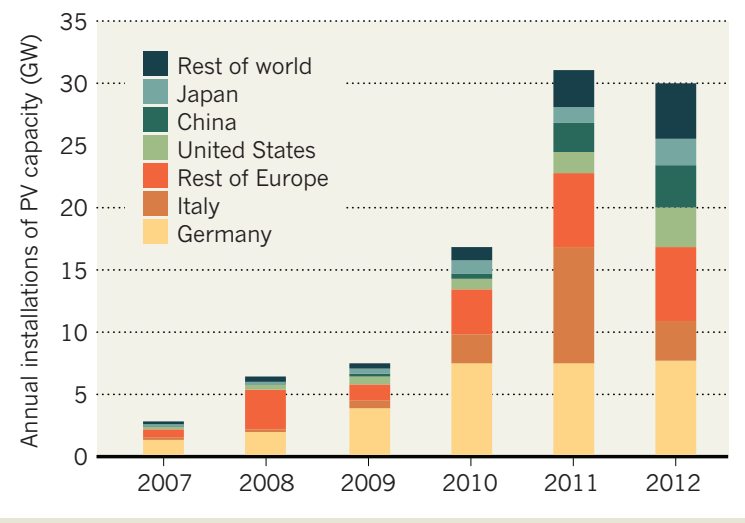

COMING UP

\section{MARCH}

The next winner of the US\$3-million Fundamental Physics Prize is announced at CERN in Geneva, Switzerland. go.nature.com/lr7hht

\section{0-21 MARCH}

In New York, researchers discuss the Sustainable Development Goals that will replace the United Nations' Millennium Development Goals in 2015.

go.nature.com/zwpgkh

\section{8-22 MARCH}

Results from the Mars Curiosity rover and the GRAIL mission to map the Moon's gravity are released at the Lunar and Planetary Science Conference in The Woodlands, Texas. go.nature.com/eab6yw

biomedical agency, but resigned in 2007 in relation to a legal case involving a cancer diagnostics firm that he and his wife had founded (see Nature 449, 760-761; 2007). Bréchot succeeds Alice Dautry, who got the Pasteur Institute back on track after her predecessor had been evicted amid bitter staff disputes. Dautry had served the maximum two terms in office; Bréchot begins a fouryear term on 1 October.

\section{CORRECTION}

The item 'Go-ahead for iPS' (Nature 494, 286-287; 2013) gave the wrong location for the review board that approved the iPS-cell study. It was the Institute for Biomedical Research and Innovation in Kobe.

\section{$\rightarrow$ NATURE.COM}

For daily news updates see: www.nature.com/news 